\title{
Multinational Enterprises and Social Capital as Location Factor:
}

\author{
A Review \\ Kurt Pedersen ${ }^{2}$, Gunnar Lind Haase Svendsen ${ }^{1} \&$ Gert Tinggaard Svendsen ${ }^{2}$ \\ ${ }^{1}$ University of Southern Denmark, Denmark \\ ${ }^{2}$ University of Aarhus, Denmark \\ Correspondence: Gunnar Lind Haase Svendsen, University of Southern Denmark, Denmark. E-mail: \\ glhs@sam.sdu.dk \\ Received: June 28, 2013 \\ Accepted: July 12, 2013 \\ Online Published: August 19, 2013 \\ doi:10.5430/bmr.v2n3p81 \\ URL: http://dx.doi.org/10.5430/bmr.v2n3p81
}

\begin{abstract}
It is generally assumed that multinational enterprises (MNEs) are more volatile than local firms. From the viewpoint of host countries, the volatility of MNE subsidiaries is often seen as a problem. Therefore it becomes relevant to look for ways to reduce the volatility of multinational activity across borders. We review the literature and identify a gap regarding social capital as a potential instrument for reducing the level of volatility. An existing stock of social capital may be advantageous not only to the host country but also to the MNE in the sense that optimal in-company resource allocation and profits could be improved even further. Thus, the dominating theory of FDI (Foreign Direct Investment), the eclectic paradigm as developed by John Dunning, offers a relevant opportunity to fill a gap in the literature and include social capital in FDI decisions as a new location factor.
\end{abstract}

Keywords: Multinational enterprises, Host country, Volatility, Social capital, Social trust, Profits, Foreign direct investment, Location factor

\section{Introduction}

Multinational enterprises (MNEs) are strong market actors in the international resource allocation process. Volatility appears to be a somewhat derogative characterization of the plain fact that reallocation of resources is much closer at hand for the internationally operating firm, which geographically spans more opportunities than nationally operating firms (Dunning, 1981; Lund, 1944). Reacting to changing opportunities implies starting or expanding business activities in some places, while reducing or terminating operations in other locations. One immediate consequence is that the relationship between the multinational enterprise and the host country becomes prominent.

In John Dunning's (1981) eclectic Ownership-Location-Internalization (OLI) framework, O indicates the Ownership advantages of a MNE (e.g. technology or marketing skills), $\mathbf{L}$ indicates Location advantages, i.e. country specific advantages (e.g. a large market, cheap factor inputs or a liberal business climate), and $\mathbf{I}$ indicates Internalization advantages (such factors which promote FDI rather than other forms of internationalization, e.g. export). For a FDI (Foreign Direct Investment) to become a success, it is necessary that all three conditions are fulfilled. In this framework we add to the theory of Dunning by suggesting that social capital may enter the OLI framework as an important L-factor.

Firms become multinational when they invest across borders. Literature offers a number of reasons for such investment, but, overall, focus is on sustainability of the company and long-run profitability. By definition MNEs operate subsidiaries in a set of different business environments and consider FDI in another set of investment environments. It goes almost without saying that the character of the environment is important for the investment decision. Our point is that social capital is one decisive dimension of the 'environment' or, more specifically, a location factor that should possibly be included among the L-factors in the OLI framework.

Hence, the article attempts to bridge this eclectic paradigmatic thinking with the concept of social capital as developed by Bourdieu, Putnam and others in recent decades (Svendsen \& Svendsen, 2009). In line with Putnam (1993: 35-36), we define social capital as networks, norms and trust that enhance co-ordination and co-operation between various people and groups within a country or a firm. Trust is here broadly understood as acceptance of vulnerability in order to obtain future gains - be it economic or non-economic - wherefore vulnerability can be seen 
as the "price of trust" (Barbalet, 2009: 369), implying potential economic, social as well as emotional costs. This brings in social capital as a policy variable with a potential effect on the location of FDIs across countries. Such a review of the literature is helpful as it might give rise to empirical investigations that may relate social capital as a "missing link" to business behavior. This approach is missing in the literature.

To the best of our knowledge, there has been no earlier attempt in the literature to consider how social capital may reduce volatility of MNE investments (see Ostrom \& Ahn, 2009, for an overview). Our review of the literature points to the potential importance of social capital in the MNE setting and the argumentation is as follows: Section 2 introduces the volatility of multinational enterprises. Section 3 introduces the concept of social capital and links it to international business. Section 4 concludes and gives some suggestions for future research.

\section{The Inherently Volatile MNE}

\subsection{The Liability of Foreignness}

It would be fair to argue that the characteristic volatility of MNEs is in fact narrowly related to the very concept of a multinational enterprise. While, in the early MNE literature the definition was a company with productive operations in at least five foreign nations, the modern definition offered by Dunning and Lundan (1981) is a company with value creating business operations in more than one country. For the purpose of the present paper, the exact definition may not matter, but the earlier understanding of the multinational concept fits better with the argument.

What is important is the term "foreign". Stephen Hymer (1976) coined the term Liability of Foreignness as a brief but powerful concept to describe that a company that establishes operations in another country is handicapped by knowing less about this country and its market than indigenous firms that already serve it. Liability of foreignness includes a number of factors - macro-economic, institutional, competitive etc. - which tend to vary between nations. Distance still matters and may be assessed by, for instance, a CAGE analysis (Ghemawat, 2001). In general, before succeeding in a new market, much knowledge must be gathered and much business planning accomplished. The "positioning school" - a Harvard approach much in the spirit of Hymer (1960) - has provided a number of instruments for this purpose.

In markets or in periods when time is crucial - for instance due to short product cycles - and time compression costs therefore are significant, the MNE can choose to acquire a foreign firm in order to reduce, but not evade, costs related to Liability of Foreignness. This is to a large extent what has happened over the last decades: green-field investments have been overtaken in importance by mergers and acquisitions, or by brown-field investments.

If this was the whole story, all business would be local - but clearly it is not. So how and why do multinational enterprises overcome the obstacles caused by their "foreignness"? The answer given by Hymer (1960) was simple: companies use firm specific advantages which could - and can - be seen as the assets to weigh against the liability of foreignness. Embedded in this approach is a "centre-periphery" thinking: the superior commercial forces of the centre expand their reach and gradually penetrate and dominate the periphery. Thus, in the 1960s and 1970s, MNE and multinational activity found its political place in the North-South and East-West dialogues and conflicts. The conception of the MNE as a "political agent" was de-dramatized in the 1980s by the almost simultaneous contributions by Buckley and Casson (1985), Wernerfelt (1984) and Barney (1991). Entrepreneurship and company resource building came to the fore, and this efficiently removed the exploitation aspect. The assets leading to competitiveness were now seen as the consequences (and purpose) of a firm specific process. Contrary to the opinion of Hymer, the lunch was no longer free.

Over time companies invest in a number of competences across value-adding activities and thus create competitive advantages. As new evidence convincingly shows, competitiveness can be built in Chinese or Indian firms as well as in American or Danish ones. In recent years FDI patterns show new configurations and the Investment Development Path (Dunning, 1981; Dunning and Narula, 1996) has enjoyed a come-back.

Liability of foreignness will exist as long as globalization has not wiped out all differences between nations. Similarly, companies incessantly work at developing new competitiveness. Firms operating at the international level must consider the balance between foreignness and competitive advantages whenever a change in business activities is being considered. The mere fact that two (sets of) variables automatically feed more changes into the strategic planning will suffice to explain why MNEs are more volatile - that is, more ready to leave a country when profits decrease. They respond to more, and more frequent, changes in business opportunities than do local companies. Perhaps social capital could be one overlooked instrument to reduce the relative volatility of MNEs. 


\section{Capital and Social Capital}

\subsection{The emergence of social capital}

In recent decades the conventional concept of (physical) capital has been expanded. Partly as a consequence of the Cambridge Capital Controversy starting in the 1950s and culminated during the 1970s combined with the inability of growth theory to account for growth rates exclusively by quantities of capital and labor, the concept of human capital emerged in the new growth theories during the 1980s and 1990s. According to this approach, investments could also take place as a systematic upgrading of the labor force by adding knowledge or competencies. Human capital bears resemblance to the concept of the 'knowledge society' (Svendsen \& Svendsen, 2004).

As new growth theory developed, the thesis of convergence was challenged, and a search for "deeper" system parameters started. This is how social capital - network resources based on trust - came to stage and soon became a research topic in its own right. As it has been formulated by Robert D. Putnam (2000: 19): "[Just] as a screwdriver (physical capital) or a college education (human capital) can increase productivity (both individual and collective), so too social contacts affect the productivity of individuals and groups". The definitions of this 'new' kind of capital vary. However, the most widely used are those offered by Bourdieu, Coleman and Putnam - later to be introduced in this section.

From a social capital view, societies differ in social structure and relations - something which is also mirrored in the public and private enterprises of a country, although some organizations (to a certain degree, at least) may also possess their own particular 'organizational social capital' (Svendsen \& Waldstrøm, 2013; Brink \& Svendsen, 2013).This is due to differences in durable ('sticky') cultural values (e.g. Inglehart \& Baker, 2000; Inglehart et al., 2004) and political set-ups (e.g. Rothstein, 2003) - or, most plausible, a combination of the two. This leads to a wide divergence in the degree of mutual trust among citizens. The assumption is that nations with a high level of social capital perform better than countries with low levels, and that social capital may be augmented by goal directed investments in institutional set-ups, education, etc. (Paldam \& Svendsen, 2000).

As a frame for using the concept of 'social capital' within business economics, we will in the following trace the transformation of the term 'capital' from a pure materialistic term within mainstream economics to a key concept which, gradually, contains a number of intangible forms of capital as well, such as human and social capital.

\subsection{From classical economics to social capital}

Capital comes from the Latin capitalis, derived from caput, 'head'. However, the word can be traced back even further to the ancient Greek kefalaion. This word is derived from kéfali, which also means 'head', either human or animal head. It is highly likely that capital originally meant wealth in the form of heads, e.g. a flock of sheep or a herd of cattle, which gave the owner different forms of income (milk, field hands, meat, wool, hide, etc.).

Today, 'capital' seems to invade the social sciences. Almost twenty years ago Baron \& Hannan (1994: 1122) complained about a 'plethora of capitals' in economic sociology, which according to them had led to "a minor sociological industry [which] construct sociological parallels to human capital" (op.cit.: 1123). Since then, the number of more or less exotic forms of capital has kept growing. In addition to the 'old' forms - physical, economic, human - contemporary literature contains an undergrowth of capitals including social, cultural, symbolic, religious, intellectual, natural, digital, psychological, linguistic, emotional and political capital. What the positivistic inspired capital theoreticians of the 1800s feared mostly has happened: During the 1960s it became legitimate for economists to account for (invisible) human capital. This triggered a renewed interest around 1970. As a consequence, the capital concept has continued to expand ever since, so that it now also includes non-tangible and former non-economic assets.

As such, the subsequent research in social capital reflects a breakdown within economic positivism, which permeated the early, neo-classic paradigm that can be traced back to scholars like Jevons, Menger, Walras and Marshall in the second half of the $19^{\text {th }}$ century. They shared a vision of cumulative, scientific progress and a theoretic economic science that strives to uncover economic laws regarding utility, profit maximization, demand and shortage. Such laws are assumed to be able to explain real, economic phenomena understood as production, distribution and consumption of tangible forms of capital and consumer goods.

However, even then many of the complexities of the concept of capital were realized, as can be seen in the work of the founder of the Austrian School, Carl Menger, who saw economies as largely non-predictable. In his major work, Menger (1950 [1871]) offered a cure for 'childhood diseases' within the newly established discipline of economics by coupling two simple hypotheses: 
(1) An economy is conditioned by the consumers' future expectations (empirical level)

(2) The reason for this is the 'economizing' or 'saving' orientation of human nature, i.e. the fact that a person will always attempt to satisfy as many of his material needs as possible, and satisfy his most acute needs first (ontological level)

Like his successors, Menger was exclusively interested in physical and economic capital and not immaterial forms of capital (like human and social capital). Within capital theory, his main contribution consists in identifying time as an important dimension of capital in a modern, capital-consuming economy. It is by extending the production time and using an increased number of capital goods ('goods of a higher order') that we achieve a greater output of consumer goods ('goods of a lower order'). This in contrast to an earlier static, descriptive model directed at agricultural production with fixed, annual production periods. However, Menger found it trivial to talk about a constant flow of input and output as in the forest example, where an annual logging is equaled to the number of trees planted 20 years ago. Instead, Menger transformed a retrospective-descriptive definition of capital into a prospective-causal definition (Menger, 1950 [1871]: 143). Just like later theoreticians like Joseph Schumpeter and Pierre Bourdieu, Menger thus argued for seeing economies as open, dynamic systems where uncertainty and 'errors' are essential elements. This is due to the fact that the future production of goods is constantly formed by individual consumers and innovative entrepreneurs whose actions are based on a mixture of intuition and information (op.cit.: 150.).

\section{Human capital}

A century later, during the 1960s and 1970s, it became gradually feasible for economists to "value man" as human capital (Kiker, 1971: 51). Gary Becker was the technician and Theodore W. Schultz the seminal thinker behind this first non-material form of capital. Becker's contribution consisted in rather technical calculations of revenue obtained from investment in human capital (made up by schooling, training and an investor's own time, cf. Becker, 1971: 43). He based these calculations on the assumption that "all persons are rational" (op.cit.: 50), echoing Smith's Economic man (Smith, 1997 [1766]). Without reflecting deeply about what capital is, Becker (1964: 1) was eager to find a better explanation of economic growth than measures of physical capital, primarily focusing on the impact of education (Serritzlew and Svendsen, 2011). At a more overall level, the founding father of human capital, Theodore W. Shultz, wanted to reinstall Smith's 'acquired and useful abilities' in capital theory, as "it has been all too convenient in marginal productivity analysis to treat labor as it were a unique bundle of innate abilities that are whole free of capital" (Schultz, 1971: 4). Like Becker, Schultz was quite laconic and matter-of-fact about what capital is, confining himself to talk about produced means of production as an outcome of investment of money and time. Nevertheless, a renewed interest in the capital concept was triggered and non-material forms of capital included. Schultz (op.cit.: 9) states about the missing link of human capital: "The explanation that now is clear is that we gave altogether too much weight to nonhuman capital in making these assessments. We fell into this error, I am convinced, because we did not have a concept of all capital and, therefore, failed to take account of human capital and the important part that it plays in production in a modern economy".

Within current economics, capital is broadly defined as a resource for profit maximization available to a person or an organization. More specifically, stocks of capital goods can be divided into real capital and financial capital, which in different ways are included in the production process. Real capital consists of produced production factors in the form of buildings, machines, tools, roads, railways; financial capital is liquid assets like stocks, bonds etc., which can be used to make investments in real capital.

Such definitions clearly reflect the division of labor between economics and the other social sciences that has characterized the western world throughout most of the $20^{\text {th }}$ century. Grossly speaking, economists thus gained a monopoly on studying the market forces, while sociologists, anthropologists and others within the humanities gained monopoly on studying the 'non-economic' fields, often summarized as 'social phenomena' (cf. Smart, 1993: 388). This division of labor became blurred in the last two decades of the $20^{\text {th }}$ century, at a time when various scholars made a new attempt to discover 'all capital', as Schultz had asked for. This was partly due to economic sociology research pioneered by Marc Granovetter, James Coleman and Pierre Bourdieu; partly to work by scholars within neo-institutional economics (NIE) like Oliver Williamson, Douglass North and Barry Weingast (Svendsen \& Svendsen, 2009).

Among the former, Bourdieu (1977, 1997, 2000) most radically attempted to remove what he saw as artificial boundaries between economics on the one hand and sociology and anthropology on the other. As we shall see, he did this by introducing an ambitious capital theory where the social world is integrated - also methodologically - in economics, namely as forms of capital on equal footing with the traditional forms. In addition, several other sociological and anthropological theories attempt to explain the organizational principles of the market economy in a 
broader perspective. These have roots back in classic sociology, e.g. Mauss' gift exchange and Simmel's ideas about reciprocity, understood as exchange of objects, services, information, recognition etc., that commits actors to repay in accordance with a particular, cultural system (see, e.g., Wrong, 1961; Appadurai, 1986; Granovetter, 1990). On the other side, economists within neo-institutional economics have incorporated cultural aspects as factors in the market economy (Graeff \& Svendsen, 2013).

Bourdieu's general science of the economy of practices

Bourdieu's general approach to capital means “...a general science of the economy of practices must endeavor to grasp capital and profit in all their forms and to establish the laws whereby the different types of capital (or power, which amounts to the same thing) change into one another" (Bourdieu, 1986: 243). His main ideas were developed in 1979 in two small articles in French, "Les troisétats du capital" and "Le capital social. Notes provisoires". In 1986 these ideas were combined in the important article "The forms of capital", which outlines a new interdisciplinary science based on the study of material and immaterial forms of capital. 'A general science' is based on an expansion of basic concepts within classic and neo-classic economics such as profit, economy and capital (Lebaron, 2003; Svendsen \& Svendsen, 2003).

Bourdieu saw capital as accumulated labor which, fixed in a medium, can be transmitted through history from generation to generation in visible objects outside people (materialized form), as well as invisibly, inside people (incorporated form): "Capital is accumulated labor (in its materialized form or its 'incorporated,' embodied form) which, when appropriated on a private, i.e., exclusive, basis by agents or groups of agents, enables them to appropriate social energy in the form of reified or living labor" (Bourdieu, 1986: 241).

Following this 'expanded' definition of capital, we see that it certainly is not a natural law that forms of capital merely appear as physical objects or as reified (as 'human capital') phenomena. Bourdieu's idea was to go further and operate with 'social', 'cultural' or 'symbolic' capitals; i.e. concrete resources that are part of the individual person's reasonable strategies for building and acquiring capital, by Bourdieu juxtaposed with power.

Here at the beginning of the $21^{\text {st }}$ century, there are indications that we are heading towards a new, neo-capital approach to social phenomena. This approach harbors many types of capital - tangible as well as intangible (cf. Veblen, 1908a, 1908b). These forms can all be exchanged for each other (by Bourdieu termed mutual 'convertibility'), in accordance with complex cultural norms and rules. This was precisely the type of idea that was outlined in Bourdieu's 'General science' (Bourdieu, 1979a, 19979b, 1986), so "Bourdieuconomics" should rightly be its name (Svendsen \& Svendsen, 2003). Bourdieu's focus on invisible capital can thus be claimed to pave the way for the social capital approach.

\subsection{Social capital and international business}

\section{What is social capital?}

What, then, is this intangible form of capital with, presumably, visible socio-economic effects - social capital? Bourdieu (1986: 248-49) defined social capital as a resource available for individuals at the micro level and consisting of "the aggregate of the actual or potential resources which are linked to possession of a durable network of more or less institutionalised relationships of mutual acquaintance and recognition - or in other words, to membership in a group - which provides each of its members with the backing of the collectively-owned capital". Coleman adopted social capital to economic performance as well. According to him, the words 'social' and 'capital' form a useful linkage between economics and social science. Hence, for Coleman the economists' term 'capital' implies a resource that facilitates production, while the social scientists' term 'social' refers to "aspects of social organization, ordinarily informal relationships, established for non-economic purposes, yet with economic consequences" (Coleman, 1994: 175). Like both Bourdieu and Putnam, he saw this form of capital in equal line with more traditional forms of capital: "Like other forms of capital, social capital is productive, making possible the achievement of certain ends that would not be attainable in its absence (...) In a farming community [where] one farmer got his hay baled by another and where farm tools are extensively borrowed and lent, the social capital allows each farmer to get his work done with less physical capital in the form of tools and equipment" (Coleman, 1990: 302). Finally, as already mentioned, most relevant in this context is Putnam's (1993: 35-36) famous, macro-oriented definition of social capital as "an accumulated stock of networks, norms, and trust, that facilitate co-ordination and co-operation for mutual benefit".

\section{Social capital in multinational enterprises}

Hence, to the array of capital concepts in international business we may add social capital. Like physical and human capital it is a more or less exact input-output relation. The investments go into processes that result in output. In the 
case of social capital, the input is 'good, trustworthy behavior', which gives rise to positive attitudes and smooth cooperation between various partners. Positive attitudes and cooperative skills spill over into reduced transaction costs and in consequence the output will be higher profit expectations. In case of free-rider problems, dense social networks facilitate social sanctioning in the form of social exclusion, damaging a free-rider's reputation or more formal sanctioning (cf. Coleman, 1988; Hardin, 2002; Newton, 2007; Rothstein, 2009; Nilsson et al., 2012). However, social capital can also be negative, restricting personal freedom and harm organizations and society (see e.g. Portes \& Landolt, 1996).

The argument is best understood if the MNE subsidiary is seen as a "hub of links and relations". Logistics, production, marketing and service functions establish linkages to suppliers, customers, middlemen, trade unions and other local parties with immediate impact on the subsidiary's value creation processes. Further, the governance and strategy level of the subsidiary establishes linkages to public institutions, universities, etc. As no business policy can exist in a vacuum, the set of linkages and relations will influence the way the subsidiary is conceived, attitudes to it and outside responses to the business policy. The better relations, the more positive the responses will be.

Böhm-Bawerk characterized capital into four categories: (1) point input - point output (for instance a plantation of Christmas trees), (2) flow input - point output (for instance construction of a site), (3) point input - flow output (for instance a well) and finally (4) flow input - flow output (for instance sausage production). It is obvious that physical capital can take all the forms, and after all it was - similar to other classic economists - physical capital Böhm-Bawerk had in mind. Human capital can be point input (a brief course) or a flow input (lifelong learning), but typically results in flow output.

Social capital is more like a renewable resource; it is at hand and can be changed only by a long process of trust building, made possible by expensive investments of time and energy in nurturing a social relationship. It is an expression of the business culture in a country and for past nation building.

Social capital in the context of business culture relates to the phrase coined by Bartlett \& Ghoshal (1989), namely 'organizational glue'. In the company perspective of Bartlett, Ghoshal \& Nohria, teamwork across geographical and functional areas is a tool to establish a corporate culture in order to facilitate international management of the multinational corporation (Bartlett \& Ghoshal, 1989; Nohria \& Ghoshal, 1997). Likewise social capital functions as glue that on a higher level of aggregation functions as a tie between the multinational firm, as represented by the local subsidiary, and its environment. From the viewpoint of the host nation, the function of social capital would be that the set of economic and technical advantages that a foreign direct investment brings will be enhanced by a higher degree of stability in the presence and operation of the subsidiary. From the MNE's view, the aim is to increase expected profits and reduce perceived uncertainties.

The host country can add to the 'social glue' by maintaining stable business conditions that are fair to foreign companies. Overall, this should be done by fostering non-corrupt and trustworthy institutions designed to deal with the MNEs. Building personal relations between the subsidiary management and a reliable local (and national) government is important together with being informative as to changes in the business environment and emphasizing dialogue.

In short, social capital is a 'soft', invisible but arguably socio-economically productive form of capital that is being built over time by shaping mutual relations. Inputs are management time and other resources, including financial ones, and output is a stock of mutual confidence, or trust, which lubricates cooperation. The input - the investment in time and resources - is easily understood, while the output is more evasive. But it does share some basic features with investments in physical and human capital: long-run profit should be influenced positively. One example would be the fate of Siemens in Denmark, after World War II. More than a hundred German subsidiaries were confiscated, but the probably largest one, Siemens, made business as usual. It had operated in Denmark since 1908 and become more or less identified with the electrification of the nation. It enjoyed general respect and, to some extent, was considered a local company. Thus Siemens made use of its credibility (from Latin: credere, to believe, to trust) in the form of a credit of 'good-will' and in this way survived and even stayed in a hostile climate.

Thus, the more antagonistic the MNE/host nation relation is perceived the more relevant will be the concept of social capital as location factor. Also, high degrees of uncertainty may be important at least once the subsidiary has been established: establishing and running a subsidiary are quite different matters. Looking particularly at the eclectic paradigm, the social capital concept highlights the L factor. This is in line with some modern theorizing about international MNE activity such as Matthews (2004) in his book on far Eastern multinationals and their international expansion. 


\section{Conclusion}

Our review suggested that social capital may be a missing link and a helpful concept in international business research, not least within the field of foreign direct investments and multinational management. Thus social capital and its importance when multi-national enterprises (MNEs) start-up operations should be targeted in future research and business management. Undertaking international investment decisions, social capital may turn out to be a new factor of some significance among the Location factors (L-factors) in Dunning's OLI framework. It may be equally helpful for business practice, since it summarizes a significant part of the 'business climate' in the prospective host country.

The deployment of social capital in international business may be a new and promising approach, because this intangible form of capital arguably has tangible socio-economic outcomes. Furthermore, it is highly relevant to take social capital into consideration in order to capture a more holistic picture of the general investment climate in any location. Thus the traditional neo-classic economics approach to MNE may have underestimated cultural and historical factors and future research should try to undertake more rigorous quantitative tests of the possible linkage the volatility of MNEs and social capital as a potential new location factor that may enhance profitability in FDI decisions even further.

\section{Acknowledgements}

We wish to thank two anonymous reviewers for useful comments. We dedicate this article to our co-author Kurt Pedersen, who died on June 11, 2013. Long live his memory.

\section{References}

Appadurai, A. (1986). Introduction: Commodities and the Politics of Value, In: Appadurai, A. et al. (eds.) The Social Life of Things, 3-63. Cambridge: Cambridge University Press.

Barbalet, J. (2009) A Characterization of Trust, and its Consequences. Theoretical Sociology 38: 367-382. http://dx.doi.org/10.1007/s11186-009-9087-3

Barney, J.B. (1991). Firm Resources and Sustained Competitive Advantage. Journal of Management, 17, 99-120. http://dx.doi.org/10.1177/014920639101700108

Baron, J.N., Hannan, M.T. (1994). The Impact of Economics on Contemporary Sociology. Journal of Economic Issues vol. XXXII, 111-146.

Bartlett, C.A., Ghoshal, S. (1989). Managing Across Borders. The Transnational Solution. Harvard Business School Press: Boston, Mass.

Böhm-Bawerk, E. (1971 [1891]. The Positive Theory of Capital. Libraries Press: Freeport, New York.

Böhm-Bawerk, E. (1895). The positive theory of capital and its critics. Quarterly Journal of Economics, 9, 113-131. http://dx.doi.org/10.2307/1885595

Becker, G.S (1964). Human Capital. National Bureau of Economic Research, New York.

Becker, G.S. (1971). Optimal Investment in Human Capital. In: Kiker, B.F. (ed.) Investment in Human Capital, 40-50. University of South Carolina Press: Columbia, South Carolina.

Bourdieu, P. (1977). Outline of a Theory of Practice. Cambridge University Press: Cambridge. http://dx.doi.org/10.1017/CBO9780511812507

Bourdieu, P. (1979a). Le Capital Social. Actes de la Recherche en Sciences Sociales, 30, 2-3.

Bourdieu, P. (1979b). Les Trois États du Capital Culturel. Actes de la Recherche en Sciences Sociales, 30, 3-6. http://dx.doi.org/10.3406/arss.1979.2654

Bourdieu, P. (1986). The Forms of Capital. In: Richardson, J.G. (ed.) Handbook of Theory and Research for the Sociology of Education, 241-258. Greenwood: New York.

Bourdieu, P. (1997). Le Champ Économique. Actes de la Recherche en Sciences Sociales, 119, 48-66. http://dx.doi.org/10.3406/arss.1997.3229

Bourdieu, P. (2000). Les Structures Sociales de L'économie. Seuil: Paris.

Brink, T., Svendsen, G.L.H. (2013). Social Capital or Waste of Time? Social Networks, Social Capital and 'Unconventional Alliances' among Danish Rural Entrepreneurs. Business and Management Research, 2(1), $55-68$. 
Buckley, P., Casson, M. (1985). The Economic Theory of the Multinational Enterprise. MacMillan: London.

Coleman, J.S. (1988). Social Capital in the Creation of Human Capital. American Journal of Sociology, 94, 95-121. http://dx.doi.org/10.1086/228943

Coleman, J.S. (1994). A Rational Choice Perspective on Economic Sociology. In: Smelser, N.J. \& Swedberg, R. (eds.) The Handbook of Economic Sociology, 166-178. Princeton University Press: New York.

Dunning, J. (1981). International Production and the Multinational Enterprise. Allen \& Unwin: London.

Dunning, J. (1988). Explaining International Production. Allen \& Unwin: London.

Dunning, J., Narula, R. (1996). Foreign Direct Investments and Governments: Catalysts for Economic Restructuring. Routledge: London.

Dunning, J., Lundan, S. (2008). Multinational Enterprises and the Global Economy. Edward Elgar: Cheltenham, UK.

Ghemawat, P. (2001). Distance Still Matters. Harvard Business Review, September.

Graeff, P., Svendsen, G.T. (2013). Trust and Corruption: The influence of Positive and Negative Social Capital on the Economic Development in the European Union. Quality and Quantity, 47, 2829-2846. http://dx.doi.org/10.1007/s11135-012-9693-4

Granovetter, M.S. (1990). The Old and the New Economic Sociology. In: Friedland, R. \& Robertson, A.F. (eds.) Beyond the Marketplace, 89-112. Aldine de Gruyter: New York.

Hardin, R. (2002). Trust and Trustworthiness. New York: The Russell Sage Foundation.

Hymer, S. (1976). The International Operations of National Firms. Harvard University.

Lund, A. (1944). Kapitalbevægelsesteorien og de Direkte Investeringer (Capital Movements and Direct Investments). Nationaløkonomisk Tidsskrift, 82, 28-57.

Menger, C. (1950 [1871]). Principles of Economics. New York University Press: New York \& London.

Newton, K. (2007). Social and Political Trust. In: Dalton, R.J. \& Klingemann, H.-D. (eds.) The Oxford Handbook of Political Behavior, pp. 342-361. Oxford University Press. http://dx.doi.org/10.1093/oxfordhb/9780199270125.003.0018

Nilsson, H.J., Svendsen, G.L.H., Svendsen, G.T. (2012) Are Large and Complex Agricultural Cooperatives Losing their Social Capital? Agribusiness, 28(2), 187-204. http://dx.doi.org/10.1002/agr.21285

Nohria, N., Ghoshal, S. (1997). The Differentiated Network. Jossey-Bass: San Francisco.

Ostrom, E., Ahn, T.K. (2009). The Meaning of Social Capital and its Link to Collective Action. In: Svendsen, G.T. \& Svendsen, G.L.H. (eds.) Handbook of Social Capital. The Troika of Sociology, Political Science and Economics, 17-35. Edward Elgar: Cheltenham, UK, Northampton, MA, USA.

Paldam, M., Svendsen, G.T. (2000). An Essay on Social Capital: Looking for the Fire Behind the Smoke. European Journal of Political Economy, 16, 339-366. http://dx.doi.org/10.1016/S0176-2680(99)00064-6

Portes, A., Landolt, P. (1996). The Downside of Social Capital. American Prospect 26 (May-June), $18-21$.

Putnam, R.D. (1993). Making Democracy Work: Civic Traditions in Modern Italy. Princeton: Princeton University Press.

Putnam, R.D. (2000). Bowling Alone: The Collapse and Revival of American Community. New York: Simon \& Schuster.

Rosenberg, M. (1956). Misanthropy and Political Ideology. American Sociological Review, 21, $690-695$. http://dx.doi.org/10.2307/2088419

Rothstein, B. (2003). Social Capital, Economic Growth and Quality of Government: The Causal Mechanism. New Political Economy, 8, 49-71. http://dx.doi.org/10.1080/1356346032000078723

Rothstein, B. (2009). The Universal Welfare State. In: Svendsen, G.T. \& Svendsen, G.L.H. (eds.) Handbook of Social Capital. The Troika of Sociology, Political Science and Economics, 197-211. Edward Elgar: Cheltenham, UK, Northampton, MA, USA.

Schultz, T.W. (1971). Investment in Human Capital. In: Kiker, B.F. (ed.) Investment in Human Capital, 3-21. University of South Carolina Press: Columbia, South Carolina. 
Serritzlew, S., Svendsen, G.T. (2011). Does Education Produce Tough Lovers? Trust and Bureaucrats. Journal of Comparative Policy Analysis, 131, 91-104. http://dx.doi.org/10.1080/13876988.2011.538543

Smart, A. (1993). Gifts, Bribes, and Guanxi: A Reconsideration of Bourdieu's Social Capital. Cultural Anthropology (3), 388-408. http://dx.doi.org/10.1525/can.1993.8.3.02a00060

Smith, A. (1997 [1766]). Lecture on the Influence of Commerce on Manners. In: Klein, D.B. (ed.) Reputation: Studies in the Voluntary Elicitation of Good Conduct. University of Michigan Press.

Strandskov, J., Pedersen, K. (2008). Foreign Direct Investments in Denmark before 1939: Patterns and Scandinavian Contrasts. Business History, 50(5), 619-644. http://dx.doi.org/10.1080/00076790802246053

Svendsen, G.L.H., Svendsen, G.T. (2003). The Wealth of Nations: Bourdieuconomics and Social Capital. Theory and Society, 32 (5/6), 607-631. http://dx.doi.org/10.1023/B:RYSO.0000004967.97783.c4

Svendsen, G.L.H., Svendsen, G.T. (2004). The Creation and Destruction of Social Capital: Entrepreneurship, Co-operative Movements and Institutions. Edward Elgar: Cheltenham, UK.

Svendsen, G.T, Svendsen, G.L.H. (eds.) (2009). Handbook of Social Capital. Edward Elgar: Cheltenham, UK.

Veblen, T.B. (1908a). Fisher's Capital and Income. Political Science Quarterly, 23 (1), 112-128. http://dx.doi.org/10.2307/2140944

Veblen, T.B. (1908b). On the Nature of Capital: Investment, Intangible Assets, and the Pecuniary Magnate. Quarterly Journal of Economics (1), 104-136. http://dx.doi.org/10.2307/1883967

Svendsen, G.L.H., Waldstrøm, C. (2013). Organizational Networks and Social Capital. In: Caulkins, D.D. \& Jordan, A.T. (eds.) Companion to Organizational Anthropology, 311-327. Chichester, UK: Blackwell.

Wernerfelt, B. (1984). A Resource-Based View of the Firm. Strategic Management Journal, 5(2), 171-180. http://dx.doi.org/10.1002/smj.4250050207

Wrong, D. (1961). The Oversocialized Conception of Man in Modern Sociology. American Sociological Review (2), 183-193. http://dx.doi.org/10.2307/2089854 